Gut, 1981, 22, 108-113

\title{
Jejunal water and electrolyte secretion induced by L-arginine in man
}

\author{
J E HEGARTY, P D FAIRCLOUGH,* M L CLARK, AND A M DAWSON \\ From the Department of Gastroenterology, St Bartholomew's Hospital, London
}

SUMMARY In this study a perfusion technique has been used to investigate jejunal secretion in response to the dibasic amino acid L-arginine. L-arginine at 5,15 , and $40 \mathrm{mmol} / \mathrm{l}$ in isotonic saline solutions induced net intestinal secretion of water and $\mathrm{Na}^{+}$. The structurally similar dibasic amino acid L-lysine caused net absorption at 5 and $15 \mathrm{mmol} / 1$, and only modest net secretion of water and $\mathrm{Na}^{+}$at $40 \mathrm{mmol} / \mathrm{l}$, although aborption rates of the two amino acids were similar. D-arginine (15 $\mathrm{mmol} / \mathrm{l})$ was without effect on net water and $\mathrm{Na}^{+}$absorption. L-arginine $15 \mathrm{mmol} / \mathrm{l}$ inhibited glucose-stimulated water and $\mathrm{Na}^{+}$absorption when perfused in the same intestinal segment, but was without effect when perfused in separate jejunal or ileal segments. Parenteral chlorpromazine inhibited L-arginine induced jejunal water and $\mathrm{Na}^{+}$secretion. Jejunal secretion induced by $\mathrm{L}$ arginine thus appears not to be due to passive osmotic water flow, nor to release of circulating secretagogues. Stimulation of a mucosal secretory process is most likely to be the mechanism.

The role of intraluminal factors in the control of normal intestinal water and electrolyte homeostasis is poorly understood. Actively transported sugars and most amino acids stimulate intestinal absorption of water and $\mathrm{Na}^{+}$ion. Hellier et al.,1 however, showed that the dibasic amino acid L-arginine caused water and $\mathrm{Na}^{+}$secretion when perfused in the human jejunum. The mechanism of this secretion was not understood. We have therefore reinvestigated the phenomenon of intestinal secretion induced by $\mathrm{L}$-arginine.

Experiments have been performed to determine the effect of L-arginine on net water and sodium transport in the human jejunum and to compare this with the effects of the structurally similar dibasic amino acids D-arginine and L-lysine. The possibility that $\mathrm{L}$-arginine releases circulating secretagogues has been examined in vivo, and inhibition of L-arginine induced secretion by chlorpromazinea known inhibitor of cholera toxin induced secretion ${ }^{2}$ - has been demonstrated.

\section{Methods}

PERFUSION SOLUTIONS

All perfusion solutions were rendered iso-osmotic

*Address for correspondence: Dr P D Fairclough, Department of Gastroenterology, St Bartholomew's Hospital, West Smithfield, London EC1A 7BE.

Received for publication 16 October 1980
$(290 \mathrm{mOsm} / \mathrm{kg}$ ) by the addition of sodium chloride and contained the non-absorbable marker polyethylene glycol (PEG, mw 4000) at a concentration of $2.5 \mathrm{~g} / 1$ labelled with $1 \mu \mathrm{Ci}$ of ${ }^{14} \mathrm{C}$ PEG/l. Although PEG itself has been shown to induce intestinal secretion during jejunal perfusion studies in man, ${ }^{3}$ secretion was significant only at higher concentrations than those used in the present study. In addition, as all the solutions used in our study contained the same amount of PEG, comparisons between them will still be valid. The $\mathrm{pH}$ of the solution was adjusted to 7.0 by the addition of $1 \mathrm{M}$ $\mathrm{NaOH}$ of $\mathrm{HCl}$ as appropriate. The amino acids and glucose were obtained from standard commercial sources and were of the highest available purity. The amino acids contained no ninhydrin-positive contaminants on ion exchange chromatography.

\section{INTESTINAL PERFUSION STUDIES}

Normal adult volunteers aged 20 to 55 years were intubated with a double lumen perfusion tube incorporating a $30 \mathrm{~cm}$ perfusion segment and a proximal occlusive balloon. The tube was positioned under fluoroscopy so that the infusion orifice was within the $10 \mathrm{~cm}$ segment of jejunum distal to the duodenojejunal flexure. Perfusion solutions were infused at $15 \mathrm{ml} / \mathrm{min}$ from bottles maintained at $37^{\circ} \mathrm{C}$ using a peristaltic pump. After a 30 minute equilibration period, three 10 minute 
samples of aspirate were collected and stored at $-20^{\circ} \mathrm{C}$ until required for analysis.

The following experiments were performed:

\section{Experiment 1}

Water and solute transport was measured during jejunal perfusion with (a) L-arginine 5,15 , and $40 \mathrm{mmol} / 1$ in six subjects, (b) L-lysine 5,15 , and $40 \mathrm{mmol} / 1$ in six subjects, and (c) D-arginine $15 \mathrm{mmol} / 1$ in six subjects. The solutions were perfused in random order.

\section{Experiment 2}

To search for evidence of release of circulating secretagogues three series of experiments were performed:

a. Four subjects were intubated with a four lumen tube incorporating two adjacent perfusion segments. ${ }^{5}$ The proximal $20 \mathrm{~cm}$ segment was separated from the distal $30 \mathrm{~cm}$ segment by an occlusive balloon. The tube was positioned in the upper jejunum so that the infusion orifice of the proximal segment was just distal to the duodenojejunal flexure. The distal segment was then perfused with $10 \mathrm{mmol} / \mathrm{l}$ glucosesaline at $15 \mathrm{ml} / \mathrm{min}$ for 180 minutes and absorption from this segment was measured continuously. During the middle 60 minutes (study period) $40 \mathrm{mmol} / \mathrm{l} \mathrm{L}$-arginine in isotonic saline solution was perfused at $15 \mathrm{ml} / \mathrm{min}$ in the proximal perfusion segment. The efficiency of the occluding balloon was tested by adding phenol red to the solution perfused in the proximal segment, checking the aspirates from the distal segment for evidence of contamination by phenol red.

b. In four subjects water and solute movement was measured continuously for 180 minutes in a
$30 \mathrm{~cm}$ jejunal segment during perfusion with $10 \mathrm{mmol} / \mathrm{l}$ glucose saline at $15 \mathrm{ml} / \mathrm{min}$. During the middle 60 minutes (study period) $40 \mathrm{mmol} / 1 \mathrm{~L}$ arginine was infused into the distal small intestine $180 \mathrm{~cm}$ from the teeth at a rate of $15 \mathrm{ml} / \mathrm{min}$ via a separate single lumen intestinal tube.

c. In three subjects water and solute movement from a $30 \mathrm{~cm}$ jejunal segment perfused at $15 \mathrm{ml} / \mathrm{min}$ with a solution containing both $10 \mathrm{mMol} / 1$ glucose and $40 \mathrm{mMol} / \mathrm{l} \mathrm{L}$-arginine was measured.

\section{Experiment 3}

In six subjects, $15 \mathrm{mmol} / 1 \mathrm{~L}$-arginine was perfused at $15 \mathrm{ml} / \mathrm{min}$ in a $30 \mathrm{~cm}$ jejunal segment and water and electrolyte movements were monitored continuously for 180 minutes. In another three subjects, chlorpromazine $(1.4 \mathrm{mg} / \mathrm{kg}$ body weight $)$ was given intramuscularly 30 minutes after the establishment of a steady state, and water and electrolyte movements were monitored for another 150 minutes.

Local Ethical Committee permission for these studies was obtained and all subjects gave fully informed consent to the procedures here described.

\section{ANALYTICAL METHODS}

Amino acid concentrations were measured using a Locarte amino acid analyser (Locarte Company, London). ${ }^{14} \mathrm{C}$ PEG was measured in an LKB 1210 Ultrobeta liquid scintillation counter, ${ }^{6}$ sodium by flame photometry using an EEL 227 instrument, chloride using an EEL chloride meter, glucose by a standard autoanalyser neocuprine method, and osmolality by freezing point depression using an Advanced osmometer. Absorption rates were calculated using previously described formulae. ${ }^{4}$ The statistical significance of differences in absorption

Table 1 Water and solute movements during jejunal perfusion with $L$-and $D$-arginine and L-lysine

\begin{tabular}{|c|c|c|c|c|c|}
\hline Amino acid & $\begin{array}{l}\text { Concn. } \\
\text { (mmolll) }\end{array}$ & $\begin{array}{l}\mathrm{H}, \mathrm{O} \text { movement } \\
(\mathrm{ml} / \mathrm{h} / 30 \mathrm{~cm})\end{array}$ & $\begin{array}{l}\mathrm{Na}^{+} \text {movement } \\
(\mathrm{mmol} / \mathrm{h} / 30 \mathrm{~cm})\end{array}$ & $\begin{array}{l}\mathrm{Cl}-\text { movement } \\
(\mathrm{mmol} / \mathrm{h} / 30 \mathrm{~cm})\end{array}$ & $\begin{array}{l}\text { Amino acid absorption } \\
(\mathrm{mmol} / \mathrm{h} / 30 \mathrm{~cm})\end{array}$ \\
\hline L-Lysine & 5 & $\begin{array}{r}(+) 66.8 \pm 5 \cdot 2 \\
(\mathrm{p}<0.002)\end{array}$ & $\begin{array}{c}(+) 11 \cdot 6 \pm 1 \cdot 7 \\
(P)<0.005)\end{array}$ & $\begin{array}{c}(+) 10.8 \pm 2.4 \\
(P<0.002)\end{array}$ & $\overbrace{(\mathrm{NS})}^{1.4 \pm 0.22}$ \\
\hline L-arginine & 5 & $(-) 99 \cdot 8 \pm 13.1$ & $(-) 13 \cdot 1 \pm 1 \cdot 2$ & $(-) 12 \cdot 9 \pm 2 \cdot 3$ & $1 \cdot 7^{\prime} 0 \cdot 31$ \\
\hline L-lysine & 15 & $\begin{array}{c}(+) 43 \pm 19 \cdot 1 \\
(\mathrm{P}<0.002)\end{array}$ & 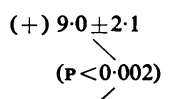 & $\begin{array}{c}(+) 8.4 \pm 1.2 \\
(P<0.002)\end{array}$ & $\overbrace{(\mathrm{NS})}^{2 \cdot 8}$ \\
\hline L-arginine & 15 & $\begin{array}{r}(-) 113 \pm 17 \cdot 1 \\
(P<0.005)\end{array}$ & 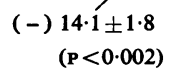 & $\begin{array}{r}(-) 13 \cdot 2 \pm 2.4 \\
(P<0.002)\end{array}$ & $\begin{array}{l}2.1 \pm 0.25 \\
(P<0.002)\end{array}$ \\
\hline D-arginine & 15 & $(+) 17.9 \pm 13.8$ & $(+) 3.6 \pm 2 \cdot 2$ & $(+) 3 \cdot 8 \pm 2 \cdot 4$ & $0.12 \pm 0.04$ \\
\hline L-arginine & 40 & $\begin{array}{c}(-) 33 \cdot 0 \pm 6 \cdot 0 \\
(\mathrm{P}<0 \cdot 0005) \\
(-) 151 \pm 12.5\end{array}$ & $\begin{array}{c}(-) 2 \cdot 4 \pm 1 \cdot 6 \\
(P<0.002) \\
(-) 14.9 \pm 2 \cdot 1\end{array}$ & $\begin{array}{c}(-) 3.2 \pm 0.9 \\
(P<0.005) \\
(-) 12.8 \pm 1.6\end{array}$ & $\begin{array}{c}2.5 \pm 0.7 \\
\overbrace{1 \times 1 S)} \\
1.8 \pm 0.8\end{array}$ \\
\hline
\end{tabular}

(+): absorption. ( - ): secretion. Values are the mean of six studies \pm SEM. 
rates was evaluated by the paired and unpaired $t$ tests where appropriate.

\section{Results}

\section{EXPERIMENT 1}

a. Net secretion of water, sodium, and chloride ion into the jejunal lumen was seen during perfusion of L-arginine (Table 1) even at $5 \mathrm{mmol} / \mathrm{l}$, the lowest concentration studied. There was a graded increase in secretion with increasing $\mathrm{L}$-arginine concentration.

b. L-lysine, however, had very different effects on jejunal water and sodium movement (Table 1). Net water and sodium absorption occurred from 5 and $15 \mathrm{mmol} / \mathrm{l} \mathrm{L}$-lysine and moderate net secretion (at only one-third of the rate observed with $5 \mathrm{mmol} / \mathrm{l}$ L-arginine) was seen with $40 \mathrm{mmol} / 1 \mathrm{~L}$-lysine.

These differences in water and sodium movement occurred despite the fact that amino acid absorption rates from equal concentrations of $\mathrm{L}$-arginine and L-lysine were identical (Table 1).

c. Whereas net secretion of water and electrolytes was seen with $15 \mathrm{mmol} / \mathrm{l} \mathrm{L}$-arginine. net absorption of water and sodium was seen during perfusion with $15 \mathrm{mMol} / \mathrm{l} \mathrm{D}$-arginine, despite the fact that $\mathrm{D}$ arginine was absorbed at only $6 \%$ of the rate of L-arginine (Table 1). The differences between absorption rates of water, sodium, and chloride are highly significant $(\mathrm{P}<0.005$ or less, Table 1$)$.

\section{EXPERIMENT 2}

The results of this experiment are summarised in Tables 2 and 3. Net absorption of water and sodium ion was seen during perfusion of $10 \mathrm{mmol} / 1$ glucose in the jejunum. This absorption was unaffected by simultaneous perfusion of either (a) a proximal occluded jejunal segment or (b) a distal intestinal segment with $40 \mathrm{mmol} / \mathrm{l}$ L-arginine (Table 2). In contrast, when a mixture of $40 \mathrm{mmol} / \mathrm{l} \mathrm{L}$-arginine and $10 \mathrm{mmol} / 1 \mathrm{D}$-glucose was perfused in the same intestinal segment (c) there was marked inhibition of the net water and sodium ion absorption seen with glucose alone (Table 3 ). The effects of glucose and L-arginine on water and sodium absorption were additive within the limits of accuracy of the experiment. Neither glucose nor L-arginine had any effect upon the absorption of the other (Table 3).

\section{EX P ER I M E N T 3}

Jejunal perfusion of $15 \mathrm{mmol} / \mathrm{l} \mathrm{L}$-arginine in six control subjects produced water secretion of 100 $\pm 1 \mathrm{SD} 20 \mathrm{ml} / \mathrm{h}$ per $30 \mathrm{~cm}$ which was unchanged during the entire 180 minutes of steady state perfusion. In three other subjects given chlorpromazine $(1.4 \mathrm{mg} / \mathrm{kg}$ intramuscularly) there was a sustained and highly significant reversal of $\mathbf{L}$-arginine induced water secretion (which was greater than 3 SD from the mean of water secretion rates in the control subjects) beginning between 60 and 90 minutes after

Table 2 Solute and water movements during jejunal perfusion of $10 \mathrm{mmol} / \mathrm{l}$ D-glucose: effect of simultaneous perfusion of $40 \mathrm{mmol} / \mathrm{l}$ L-arginine in $(A)$ jejunum and $(B)$ distal small intestine in four normal subjects

\begin{tabular}{|c|c|c|c|c|c|c|}
\hline \multirow[t]{2}{*}{ Transport } & \multicolumn{3}{|l|}{ A. Jejunum } & \multicolumn{3}{|c|}{ B. Distal small intestine } \\
\hline & Control $^{1}$ & Study period & Control $^{2}$ & Control $^{1}$ & Study period & Control $^{2}$ \\
\hline $\begin{array}{l}\text { Water }(\mathrm{ml} / \mathrm{h} / 30 \mathrm{~cm}) \\
\mathrm{Na}^{+}(\mathrm{mmol} / \mathrm{h} / 30 \mathrm{~cm}) \\
\mathrm{C} 1(\mathrm{mmol} / \mathrm{h} / 30 \mathrm{~cm}) \\
\text { Glucose }(\mathrm{mmol} / \mathrm{h} / 30 \mathrm{~cm})\end{array}$ & $\begin{array}{l}100 \pm 14 \cdot 2 \\
12 \cdot 2 \pm 2 \cdot 4 \\
11 \cdot 4 \pm 3 \\
8 \cdot 1 \pm 0 \cdot 9\end{array}$ & $\begin{array}{r}101 \cdot 7 \pm 10 \cdot 3 \\
13 \cdot 5 \pm 1 \cdot 9 \\
13 \cdot 1 \pm 2 \cdot 1 \\
7 \cdot 9 \pm 0 \cdot 5\end{array}$ & $\begin{array}{r}102 \cdot 5 \pm 8 \cdot 1 \\
13 \cdot 3 \pm 2 \cdot 0 \\
12 \cdot 9 \pm 1 \cdot 4 \\
8 \cdot 3 \pm 0 \cdot 4\end{array}$ & $\begin{array}{r}129 \pm 13 \cdot 3 \\
13 \cdot 2 \pm 2 \cdot 5 \\
14 \cdot 1 \pm 2 \cdot 9 \\
8 \cdot 3 \pm 0 \cdot 6\end{array}$ & $\begin{array}{r}132 \pm 13 \cdot 4 \\
14 \cdot 2 \pm 3 \cdot 1 \\
13 \cdot 9 \pm 3 \cdot 0 \\
8 \cdot 9 \pm 0 \cdot 5\end{array}$ & $\begin{array}{r}132 \pm 15 \\
12 \cdot 8 \pm 2 \cdot 5 \\
13 \cdot 8 \pm 1 \cdot 7 \\
8 \cdot 4 \pm 0.3\end{array}$ \\
\hline
\end{tabular}

Table 3 Solute and water movements during jejunal perfusion with L-arginine (40 mmol/l) D-glucose (10 mmol/l), and a mixture of D-glucose $(10 \mathrm{mmol} / \mathrm{l})$ and L-arginine $(40 \mathrm{mmol} / \mathrm{l})$ in six subjects

\begin{tabular}{|c|c|c|c|c|c|}
\hline \multirow{3}{*}{$\begin{array}{l}\text { Perfusion solution } \\
\text { L-arginine }(40 \mathrm{mmol} / \mathrm{l})\end{array}$} & \multicolumn{3}{|l|}{ Transport } & \multicolumn{2}{|l|}{ Absorption } \\
\hline & $\begin{array}{l}\text { Water } \\
(\mathrm{ml} / \mathrm{h} / 30 \mathrm{~cm})\end{array}$ & $\begin{array}{l}\mathrm{Na}^{+} \\
(\mathrm{mmol} / \mathrm{h} / 30 \mathrm{~cm})\end{array}$ & $\begin{array}{l}\text { C1 } \\
(\mathrm{mmol} / \mathrm{h} / 30 \mathrm{~cm})\end{array}$ & $\begin{array}{l}\text { Glucose } \\
(\mathrm{mmol} / \mathrm{h} / 30 \mathrm{~cm})\end{array}$ & $\begin{array}{l}\text { Arginine } \\
(\mathrm{mmol} / \mathrm{h} / 30 \mathrm{~cm})\end{array}$ \\
\hline & $(-) 129 \pm 18 \cdot 1$ & $(-) 12 \cdot 9 \pm 2 \cdot 1$ & $(-) 13 \cdot 7 \pm 3 \cdot 0$ & 一 & $2 \cdot 1 \pm 0 \cdot 7$ \\
\hline Glucose $(10 \mathrm{mmol} / \mathrm{l})$ & $\begin{array}{c}(+) 113 \cdot 5 \pm 10 \cdot 2 \\
(P<0.002)\end{array}$ & $\begin{array}{r}(+) \quad 13.3 \pm 2.8 \\
(\mathrm{P}<0.005)\end{array}$ & $\begin{aligned}(+) & 14 \cdot 1 \pm 1 \cdot 7 \\
& (\mathrm{P}<0.002)\end{aligned}$ & ${ }_{(\mathrm{NS})}^{8.0 \pm 0.6}$ & - \\
\hline $\begin{array}{l}\text { Glucose }(10 \mathrm{mmol} / \mathrm{l}) \\
\text { L-arginine }(40 \mathrm{mmol} / \mathrm{l})\end{array}$ & $(+) \quad 10 \cdot 1 \pm 15 \cdot 3$ & $(+) \quad 1 \cdot 7 \pm 1 \cdot 1$ & $(+) \quad 2 \cdot 3 \pm 1 \cdot 4$ & $8 \cdot 2 \pm 1 \cdot 0$ & $1 \cdot 9 \pm 0.4$ \\
\hline
\end{tabular}

Results are mean of six studies \pm SEM. ( - ): secretion. $(+)$ : absorption. 


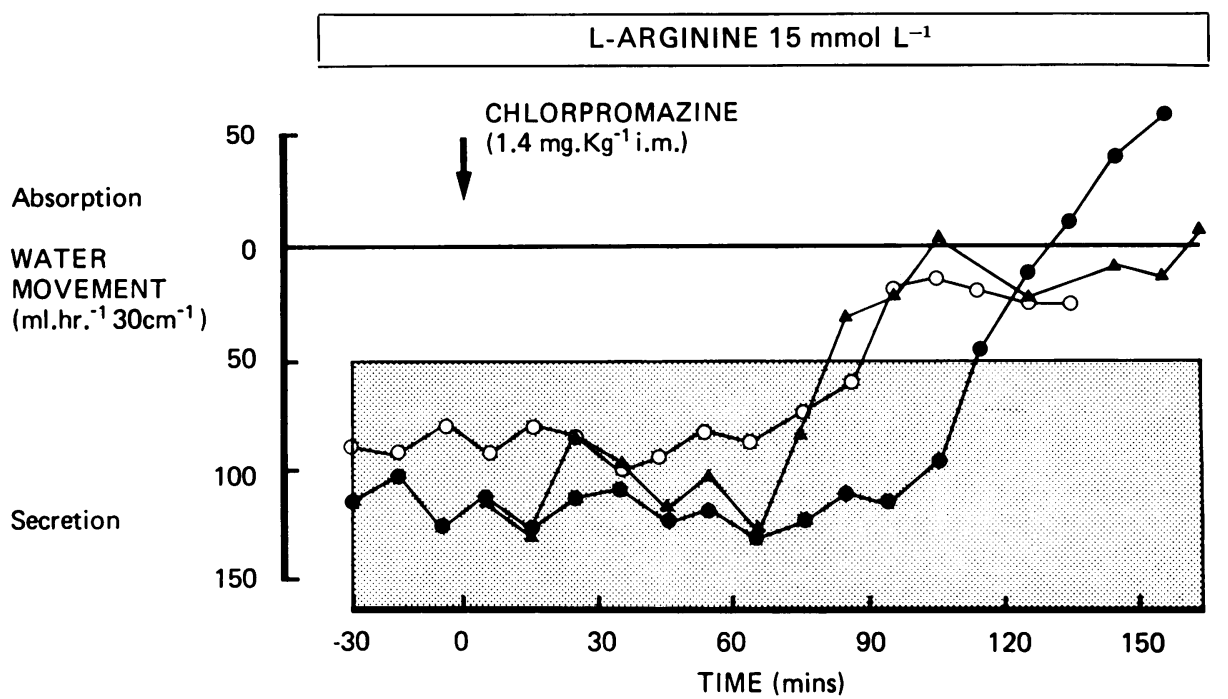

Fig. Effect of chlorpromazine on jejunal water secretion induced by perfusion of $15 \mathrm{mmol} / \mathrm{l}$ $L$-arginine in isotonic saline solution. The hatched area is the normal range of $L$-arginine induced water secretion (mean $\pm 3 S D$ ) in six normal subjects. $\bigcirc-\bigcirc,-\bullet$, and $\mathbf{\Delta}-\mathbf{\Delta}$ indicate three other subjects given chlorpromazine $1.4 \mathrm{mg} / \mathrm{kg}$ intramuscularly at a time 0 .

administration of the drug, and persisting to the end of the experiment (Figure).

\section{Discussion}

Stimulation of intestinal electrolyte secretion by a number of amino acids and monosaccharides ${ }^{8}{ }^{9}$ has been demonstrated in vitro, but in vivo in man only L-arginine has been shown to have this effect. ${ }^{1}$ Hellier et al. ${ }^{1}$ attributed the secretion to a toxic effect of L-arginine on the mucosa but did not investigate the mechanism of the secretion.

Using our double lumen perfusion system in the human jejunum, there is normally no significant net water or $\mathrm{Na}^{+}$absorption from isotonic saline solutions. ${ }^{1011}$ Low concentrations of glucose,$^{10}$ amino acids, ${ }^{1112}$ peptides, ${ }^{11}$ or bicarbonate ion $^{13}{ }^{14}$ in the perfusate stimulate significant net water and $\mathrm{Na}^{+}$ absorption. L-lysine at 5 and $15 \mathrm{mmol} / \mathrm{l}$ seems to share this property. In this study L-arginine, however, induced highly significant water and $\mathrm{Na}^{+}$ secretion over the concentration range $5-40 \mathrm{mmol} / \mathrm{l}$. We have no ready explanation for the fact that Hellier et al. were able to show secretion of water and $\mathrm{Na}^{+}$only at concentrations of L-arginine above $10 \mathrm{mmol} / 1$. L-lysine at $40 \mathrm{mmol} / 1$ also causes secretion but is a much less powerful stimulus than L-arginine. These differences in the effect of $\mathbf{L}$ lysine and L-arginine are surprising in view of the similarities in molecular structure, size, $\mathrm{pK}$ values, and absorption rates of the two amino acids.
Because the absorption rates of L-lysine and Larginine are similar, the residual concentration of osmotically active amino acid in the intestinal lumen is likewise similar, suggesting that the secretory effect of L-arginine is not due purely to the osmotic effect of unabsorbed solute. This impression is confirmed by the studies with $\mathrm{D}$-arginine. $\mathrm{D}$ and L-arginine are stereoisomers and thus have identical physicalchemical characteristics. As expected, the naturally occurring L-isomer was absorbed much more rapidly than the D-isomer when both were perfused at $15 \mathrm{mmol} / 1$. The residual intraluminal concentration of D-arginine was therefore greater than that of L-arginine and yet D-arginine did not cause secretion of water and $\mathrm{Na}^{+}$ion. These differences between the effects of D- and L-arginine might indicate a stereospecific effect, but could equally well be due to the presumably lower concentrations of the D-isomer within the epithelium. These observations, however, do seem to exclude the possiblity that L-arginine induces intestinal secretion by purely osmotic mechanisms.

The possibility that L-arginine could be producing secretion by releasing circulating secretagogues has been considered. Release of a variety of endogenous hormones after intravenous L-arginine is well documented. ${ }^{1516}$ Post-prandial rise of levels of a variety of gastrointestinal hormones has been demonstrated and some of these, including secretin, ${ }^{17}$ glucagon, ${ }^{18}$ and somatostatin, ${ }^{19}$ when infused intravenously have been shown to modify the intestinal 
transport of water and electrolytes, albeit at unphysiological plasma levels. Furthermore, intravenous administration of a mixture of gastrin, GIP, cholecystokinin, glucagon, and secretin producing plasma levels similar to those after a meal induces net secretion of water and $\mathrm{Na}^{+}$ion during jejunal perfusion of electrolyte solutions in man. ${ }^{20}$ Release of circulating secretagogues from the intestine during L-arginine perfusion was evaluated using the double perfusion technique. A submaximal stimulation of water and $\mathrm{Na}^{+}$absorption was induced by $10 \mathrm{mmol} / 1$ D-glucose to render more obvious any subtle effects on water and $\mathrm{Na}^{+}$movement induced by circulating hormones. L-arginine produced unequivocal reversal of glucose-associated water and $\mathrm{Na}^{+}$absorptionwhen perfused in the same intestinal segement but was without effect when perfused in jejunal or distal intestinal segments. These observations strongly suggest that circulating secretagogues are not a major mediator of the intestinal secretion induced by $\mathrm{L}$ arginine, although a minor effect cannot be excluded with the methodology used in this study. The results also indicate that absorbed circulating $L$-arginine is not responsible for the secretion.

Phenothiazines inhibit intestinal secretion in rabbit $^{21}$ and human ${ }^{2122}$ intestine in vitro, inhibit cholera toxin induced jejunal secretion in the mouse in vivo, ${ }^{2}$ and reduce stool fluid losses in human cholera. ${ }^{23}$ They appear to act by an effect on intracellular calcium dependent regulator protein (calmodulin), which is postulated to be an important regulator of intestinal ion transport. ${ }^{2122}$ The inhibition by chlorpromazine of water and electrolyte secretion induced by L-arginine therefore suggests that L-arginine also acts via calmodulin. However, the cellular effects of chlorpromazine are protean and include membrane stabilisation, ${ }^{24}$ displacement of membrane bound calcium, ${ }^{25}$ and increased membrane permeability, ${ }^{26}$ all of which could theoretically affect intestinal absorptive and secretory function. Preliminary experiments in our laboratory indicate that intestinal secretion induced by $D$ mannitol, which is generally considered to be purely osmotic in origin, is unaffected by chlorpromazine, suggesting that the effect of chlorpromazine on passive intestinal permeability is not likely to be of importance in its inhibition of L-arginine induced secretion. However, the precise cellular mechanism of L-arginine induced secretion in man is at present unknown. Further studies are being carried out to characterise the process.

The authors wish to thank the North East Thames Regional Health Authority, the Joint Research Board of St. Bartholomew's Hospital, The Nestlé
Company, and the Wellcome Trust for financial support and Mr M J Kelly for expert technical assistance.

\section{References}

${ }^{1}$ Hellier MD, Thirumalai C, Holdsworth CD. The effect of amino acids and dipeptides on sodium and water absorption in man. Gut 1973; 14: 41-5.

${ }^{2}$ Holmgren J, Lange S, Lonnroth I. Reversal of cyclic AMP mediated intestinal secretion in mice by chlorpromazine. Gastroenterology 1978; 75: 1103-8.

${ }^{3}$ Davis GR, Santa Ana CA, Morawski SG, Fordtran JS. Inhibition of water and electrolyte absorption by polyethylene glycol (PEG). Gastroenterology 1980; 79: 35-9.

${ }^{4}$ Sladen GE, Dawson AM. Further studies on the perfusion method of measuring intestinal absorption in man. The effects of a proximal occlusive balloon and a mixing segment. Gut 1970; 11 : 947-54.

${ }^{5}$ Wright JP, Barbezat GO, Clain JE. Jejunal secretion in response to a duodenal mixed nutrient perfusion. Gastroenterology 1979; 76: 94-8.

${ }^{6}$ Wingate DL, Sandberg RJ, Phillips SF. A comparison of stable and $\mathrm{C}^{14}$ labelled polyethylene glycol as volume indicators in the human jejunum. Gut 1972; 13: 812-5. ${ }^{7}$ Snedecor GW, Cochrane WG. Statistical methods 6th ed. Iowa: Iowa State University Press, 1937.

${ }^{8}$ Powell DW, Binder HJ, Curran P. Electrolyte secretion by the guinea pig ileum in vitro. Am J Physiol 1972; 223: 531-7.

${ }^{9}$ Munck BJ. The effects of sugar and amino acid transport on transepithelial fluxes of sodium and chloride of short circuited rat jejunum. J Physiol 1972; 223: 699-717.

${ }^{10}$ Sladen GE, Dawson AM. Interrelationships between the absorption of glucose, sodium and water by the normal human jejunum. Clin Sci 1969; 36: 119-32.

${ }^{11}$ Silk DBA, Fairclough PD, Park NJ, Lane AE, Webb JP, Clark ML, Dawson AM. A study of relations between the absorption of amino acids, dipeptides, water and electrolytes in the normal human jejunum. Clin Sci Molec Med 1975; 49: 401-8.

${ }^{12}$ Adibi SA. Leucine absorption rate and net movement of sodium and water in human jejunum. Am J Physiol 1970; 28 : 753-7.

${ }^{13}$ Sladen GE, Dawson AM. Effect of bicarbonate on sodium absorption by the human jejunum. Nature 1968; 218: $267-8$.

${ }^{14}$ Turnberg LA, Fordtran JS, Carter NW, Rector FC. Mechanism of bicarbonate absorption and its relationship to sodium transport in the human jejunum. $J$ Clin Invest 1970; 49: 548-56.

${ }^{15}$ Merimee TJ, Lillicrap DA, Rabinowitz D. Effect of arginine on serum levels of human growth hormone. Lancet 1965; 2: 668-70.

${ }^{16}$ Unger RH, Aguilar-Paradar E, Muller WA, Eisentraut AM. Studies of pancreatic alpha cell function in normal and diabetic subjects. $J$ Clin Invest 1970; 49: 837-48.

${ }^{17}$ Hicks T, Turnberg LA. The influence of secretin on ion transport in the human jejunum. Gut 1973; 14: 485-90. 
${ }^{18}$ Hicks T, Turnberg LA. The effect of glucagon and secretin on salt and water transport in the human jejunum. Gut 1972; 13: 854.

${ }^{19} \mathrm{Krejs}$ GJ, Browne R, Raskin P. Effect of intravenous somatostatin on jejunal absorption of glucose amino acids, water and electrolytes. Gastroenterology 1980; 78: 26-31.

${ }^{20}$ Poitras P, Modigliani R, Bernier J-J. Effect of a combination of gastrin, secretin, cholecystokinin, glucagon and gastric inhibitory polypeptide on jejunal absorption in man. Gut 1980; 21 : 299-304.

${ }^{21}$ Ilundain $\mathrm{A}$, Naftalin RJ. Role of $\mathrm{Ca}^{2+}$-dependent regulator protein in intestinal secretion. Nature 1979; 279: 446-8.

${ }^{22}$ Smith PL, Field M. In vitro antisecretory effects of trifluoperazine and other neuroleptics in rabbit and human small intestine. Gastroenterology 1980; 78: 1545-53.

${ }^{23}$ Rabbani GH, Greenough WB III, Holmgren J, Lonnroth I. Chlorpromazine reduces fluid-loss in cholera. Lancet 1979; 1: 410-2.

${ }^{24} \mathrm{~K}$ want WO, Steveninck $\mathrm{J}$ Van. The influence of chlorpromazine in human erythrocytes. Biochem Pharmacol 1968; 17: 2215-23.

${ }^{25} \mathrm{~K}$ want WO, Seeman P. The displacement of membrane calcium by a local anaesthetic (chlorpromazine). Biochim Biophys Acta 1969; 193: 338-49.

${ }^{26}$ Seeman P, Kwant WO, Goldberg M, Chan-Wong M. The effects of ethanol and chlorpromazine on the passive membrane permeability to $\mathrm{Na}^{+}$. Biochim Biophys Acta 1971; 241 : 349-55. 